\title{
Organic beekeeping in Russia
}

\author{
L.A. Osintseva, V.L. Petukhov*, A.I. Zheltikov, V.G. Marenkov, and V.V. Gart
}

Federal State Budgetary Educational Institution of Higher Education, Novosibirsk State Agrarian University, Novosibirsk, Russia

\begin{abstract}
In our research firstly we provide to generalized conceptual basis for the characteristics of organic beekeeping in Russia, second determine the impact of organic beekeeping on the productivity and the third quality of beekeeping products, to assess the possibility. To assess the problems associated with some of the main parameters, we conducted literature review and analysis of beekeeping products obtained in an apiary that implements the principles of organic beekeeping in the south of Western Siberia (Vengerovo village, Novosibirsk region). Article investigates theoretical and practical aspects of the orientation of apiaries to the production of organic products in the context for growing level of competition.
\end{abstract}

\section{Introduction}

Currently, the actual problem of Russian beekeeping is the sale of the resulting products. This leads an increase in the level of competition among manufacturers. One of the ways to increase the competitiveness of beekeeping farms is to obtain organic beekeeping products, since, along with the increasing popularity of healthy nutrition and a healthy lifestyle, the average premium for organic products relative to those produced using traditional technology is about $30-50 \%$ [1]. For example, the method of questionnaire assessments in identifying the price preferences of consumers of organic honey among the population of the Republic of Crimea showed that the optimal price is the price of 850, and for inorganic honey - 320 rubles. for 0.5 liters (a representative sample was 440 people). More than half of the respondents $(57 \%)$ are willing to overpay for organic honey. Organic honey is included in the diet of $87 \%$ of respondents [2]. The idea of "One health" is being developed both at the national and international levels, and the introduction of organic (ecological) agricultural production, monitoring of zoonoses and trans-limiting diseases of animals and humans is indicated as the main direction in the implementation of this concept. On the example of organic beekeeping, the requirements for its organization and technology are outlined [3].

According to the Research Institute of Organic Agriculture (FiBL) and the International Federation of Organic Agriculture Movements (IFOAM-Organics International), the countries with the most organic agricultural land include Australia, Argentina and Spain $(35,7 ; 3,7$ and 2,4 million hectares, respectively). In addition to land designated for organic agriculture, organic land includes wild picking areas, aquaculture, forests and pastures on

*Corresponding author: lao08@mail.ru 
non-agricultural land, and areas for beekeeping. These areas in 2019 to 35 million hectares, and all organic areas combined to 107,4 million hectares. In 2019, there were at least 3,1 million organic producers worldwide, located in Asia, followed by Africa (27\%), Europe (14\%) and Latin America (7\%). As of 2020, 72 countries have fully implemented organic rules, 22 countries had rules that were not fully implemented, 14 countries developed legislation [4].

Federal Law № 280-FL "On Organic Products and on Amendments to Certain Legislative Acts of the Russian Federation" creates a legal basis for the production and sale of organic products in Russia. After 01.01.2020, without a certification issued by an accredited company, you cannot be called an organic manufacturer in the Russian Federation. Certification of organic production in beekeeping for compliance with the Interstate Standard GOST 33980-2016 "Organic Products. Rules for production, processing, labeling and sale (CAC / GL 32-1999, NEQ) ", which came into force on January 1, 2018, which regulates the rules for organic beekeeping, is carried out by ANO" Roskachestvo " (https://roskachestvo.gov.ru/organic/).

According the independent professional association in the field of organic agriculture and biologization of agriculture, the Union of Organic Agriculture, only $0,12 \%$ (246 thousand hectares) of agricultural land in Russia is certified as organic according to international standards. The list of organic producers included in the unified state register consists of 59 enterprises (data as of 01.26.2021). The list of agricultural enterprises in Russia, certified according to international organic standards of the EU countries (Regulation 848/2018, 889/2008) and the USA (USDA ORGANIC) - includes 46 (data as of August 2020) companies [5]. Beekeeping farms in not in this list. Favorable natural and climatic conditions, a high potential need for organic honey in the resort sector, high beekeeping skills among the population give reason to assume the successful implementation of the organic apicluster project in southern Russia as a pilot project [6]. However, they should be located on the lands of certified agricultural producers or in areas where not only industrial, but also agricultural activities of the population are absent. The latter is not typical for the southern regions of the country, but characterizes the placement of apiaries in the West Siberian region. This situation creates undeniable competitive advantages for the products obtained from these apiaries. Realization of these advantages is difficult due to lack of procedure for passing voluntary certification, which is associated with its cost.

Movement of organic beekeeping took shape in Europe in the 1990s. In 1991, the European Commission was established to regulate the development of beekeeping. The first world conference of organic beekeeping under the auspices of the International Federation of Beekeeping Associations - Apimondia was held in Bulgaria in August 2010. In 2015, IFOAM created the Apiculture Forum (IAF) as a platform for discussing the problems of organic beekeeping and exchange of experience. The governing body of the Forum included representatives of organic associations and institutions from Argentina, Germany, Mexico and Switzerland: Apicon, Coopsol, Demeter, FiBL, Naturland and University Sur. With the support of IFOAM - IAF and Apimondia, in 2016 and 2017 international conferences and seminars on organic beekeeping were held in Argentina, Switzerland, Germany and Iran. According to FiBL, in 2015 in 67 countries of the world (Russia is not among them) there were 2.055 million organic bee colonies $(2.5 \%$ of the total number of bee colonies in the world) [7].

The purpose of this work is to draw attention on problems of Russian organic beekeeping. 


\section{Materials and methods}

Methodology of this study is the analysis of the requirements for organic apiaries, the legal framework regulating the quality control of organic products. The materials were publicly from available sources.

The experimental work was carried out in a private stationary apiary located in the vicinity of the village. Vengerovo, Novosibirsk region, $12 \mathrm{~km}$ from the village (55.73 180 , 76.94 007). Natural and climatic zone - northern forest-steppe, floodplain of the Tartas River. The nearest cultivated areas are located $18 \mathrm{~km}$ from the apiary. The apiary is 24 years old, the name of the apiary is Vengerovskaya. Bee colonies are kept in Dadant wood hives. There is an underground wintering house in the apiary. Reproduction of families natural swarming and organization of individual layers. Central Russian cross-breed bees (Apis mellifera mellifera). The size of the apiary varies from 17 to 27 bee colonies over the years.

The quality and safety indicators of honey, wax, pollen pollen were determined according to the requirements of the corresponding GOSTs on the basis of the accredited Center for Shared Use of Scientific Equipment of the Novosibirsk Agrarian University.

\section{Results and discussion}

Vengerovskaya apiary meets the requirements of organic production, since the production of products is based on the use of natural, biological and renewable resources. The apiary does not use genetically modified organisms and products made from them or with their help as feed, food additives, technological aids. Ionizing radiation is not used to process the received products, nano-materials and nano-particles are not used, including packaging and surfaces in contact with the product. Glass for honey and cardboard for wax are used as containers. Traditional beekeeping on the territory of the Russian Federation usually also meets the listed requirements, but food plastic is increasingly used for packaging and transportation.

At Vengerian apiary, the production of beekeeping products is documented by keeping an apiary journal, which, in addition to information about the state of bee colonies, includes information on the origin, breeding and transportation of bee colonies, measures for the prevention of diseases and their treatment, medicinal products used, feed used, and wintering results. Regarding the turnover of organic products: report of origin, types and composition of purchased and sold products in private beekeeping is usually not carried out.

Bred bee breed is adapted to the climatic and honey-collecting conditions of a particular area and is characterized by resistance to bacterial diseases, nosematosis and mycoses.

Organic apiary should be located in such a way that, within radius of $3 \mathrm{~km}$ from it, sources of nectar and pollen consist of organically grown crops and (or) wild vegetation, and within radius of $6 \mathrm{~km}$ there are no enterprises that pollute the specified area with radioactive, chemical, biological or other substances posing a danger to public health. Many personal apiaries meet these requirements. As you know, honey bees and their products are effective bioindicators for detecting and tracking changes in the quality of agricultural landscapes and native biocenoses at spatial and temporal scales $[8,9]$.

Determine the content of chemical elements in honey and bee pollen of Venetian apiary shows comparable level $\mathrm{Cu}, \mathrm{Zn}, \mathrm{Cd}$ and $\mathrm{Pb}$ in honey $(0,012-0,020 ; 1,5-2,4 ; 0,020-0,031$ and $0,000-0,009 \mathrm{mg} / \mathrm{kg}$, respectively, by elements) and bee pollen (5,4-8,5; 26,3-39,2; $0,009-0,010$ and $0,094-0,108 \mathrm{mg} / \mathrm{kg}$, respectively, by elements) with average values of these elements in bee products produced in apiaries of the Altai region, classified as organic production [10]. 
Employees of the Institute of Animal Biology of the National Academy of Agrarian Sciences of Ukraine have shown that under the conditions of traditional and certified organic agricultural production in the Polesie zone (Chernihiv and Vinnitsa regions), the level of $\mathrm{Cu}, \mathrm{Co}, \mathrm{Cr}, \mathrm{Zn}$ and $\mathrm{Cd}$ in honey, bee pollen, wax and bee tissues is reliable vary, the content of heavy metals decreases $[11,12]$. The results of our research also show that the content of heavy metals in the bee pollen collected in an apiary located in the floodplain of the $\mathrm{Ob}$ River in the city of Novosibirsk significantly exceeds $(\mathrm{Cu}-2,8-5,3, \mathrm{Zn}-30,3-$ $42,4, \mathrm{Cd}-0,19-0,27$ and $\mathrm{Pb}-0,25-0,58 \mathrm{mg} / \mathrm{kg}$ ) indicators determined in products from the Wenger apiary [13].

During the season, a bee colony builds from 5 to 8 frames of foundation, which characterizes the wax productivity of families in traditional beekeeping in Siberia. The beeswax used to make the beeswax and the beeswax produced from it meet the requirements of the standard, but the beeswax production is not certified organicThe materials used for fumigating bee colonies are of natural origin - wood, tinder fungus, propolised canvas. Honeycomb bees and drone brood are not destroyed. During the production of honey and to attract swarms, artificially synthesized repellents and attractants are not used. Brood combs are not used for honey production. Wing clipping of queen bees is not applied.

Feeding with artificial feed is not carried out in the Vengerian apiary. The shortage of forage in families, associated with climatic or other exceptional circumstances, is compensated by the setting of forage frames with honey and bee bread, produced in the apiary, from the warehouse.

To improve the food supply in industrial beekeeping, several technological approaches are used: roaming of bees, sowing of near-season crops and the creation of a "flower conveyor", feeding bee colonies. Standard balanced diet for honey bees, which would be accepted around the world, has not yet been developed [14]. In organic beekeeping in the south of Western Siberia, a successful solution to the problems of a forage base is the use of natural landscapes with rich entomophilous vegetation. It is social apidaidae strive to increase the species diversity of the collected pollen to provide a complete diet for their larvae $[15,16]$. This is a biological rationale for the need to provide honey bees with a variety of botanical sources of protein feed, which can be implemented in native biocenoses, on non-agricultural lands.

Fodder base of the Vengerian apiary is provided by a wide range of meadow forbs, the pollen grains of Legumes, Fobacea (sweet clover, clover, sainfoin, types of peas, alfalfa, rank), Asteraceae, Asteraceae (dandelion, thistle, thistle, cornflower, coriander , loprukh,), Cabbage, Brassicaceae (mustard, colza), Celery, Apiaceae (angelica, willow, kupyr,), Lamiaceae (oregano, sage, thyme, mint), Rosaceae, Rosaceae (rose hips, apple trees, raspberries ), Borachnikovs, Boraginaceae (Nonea, Comfrey), Norichnikovs, Scrophulariaceae (Veronica, Toadflax), Buckwheat, Polygonaceae, Euphorbiaceae, Euphorbiaceae; Derbennikovs, Lytraceae, Sinyukhovs, Polemoniaceae.

Honey productivity of families varies from year to year from 28 to $45 \mathrm{~kg} /$ family, depending on weather conditions, which is comparable to the indicators of apiaries in the northern forest-steppe zone of the south of Western Siberia, located in agrocenoses. The quality characteristics of honey meet the requirements of regulatory documents, as a rule, they are characterized by high enzymatic activity (diastase number varies from 16 to 29 Gotha units over the years), low water content (from 16 to $18 \%$ ), high proline content (230$450 \mathrm{mg} / \mathrm{kg}$ ).

Reducing the risk of morbidity in bee colonies is ensured by the correct choice of the location of the apiary and the breed of bees (zoned breed). The equipment is regularly mechanically cleaned and disinfected using steam (in a steam wax furnace). Steam or open fire is used to disinfect the hives. In order to protect frames, hives, honeycombs and a 
winter house from pests, sulphurous lime (polysulfide) is used as a fungicide, insecticide and acaricide, sulfur as a fungicide, acaricide, and repellent.

In case when using preventive measures has not yielded results, for the treatment of bee colonies in organic beekeeping, it is allowed to use formic, lactic, acetic, oxalic acids, as well as menthol, eucalyptus or camphor. The effectiveness of organic acids as acaricides has been shown [17]. Evaluation of the effectiveness of the treatment of bee colonies in apiaries of the Volgograd region immediately after the main honey collection with $85 \%$ formic acid, which in the form of a gel placed in $30 \mathrm{~g}$ bags, was located on the upper frames of the nest directly under the lap, showed that the degree of ripening decreased by 14,3$28,2 \%$ and did not exceed $3,8 \%$. The authors note an increase in honey productivity from 17,9 in the control and up to $27,42 \mathrm{~kg}$ in the treated groups and a decrease in the mortality of bees during the wintering period from 18,8 to $8,3 \%[18,19]$.

According to information obtained from the BIE World Animal Health Database (WAHIS) over 13 years (2005-2018), the average percentage of countries reporting varroosis in bees was stable (53.4\% of the countries surveyed) and there was a statistically significant trend towards an increase in the number of tick outbreaks during the year [20]. The problem of controlling populations of the Varroa sp. is one of the main technologies in organic beekeeping, as well as in traditional beekeeping. Residual amounts of acaricidal preparations are determined in both conventional and organic honeys. Thus, a study of 61 samples of chestnut honey (2018-2019) from Croatian registered organic and conventional beekeepers (16 and 45 samples, respectively) showed that all honey samples had residues of pollutants (eleven metals) below the permissible maximum levels and are considered safe for consumers. However, 2 out of 16 organic and 34 out of 45 samples of regular honey contained one or two synthetic acaricides (most often coumaphos), organic honey contained, on average, lower levels of coumaphos, amitraz and the metabolite amitraz [21].

To reduce the infestation of bee colonies by varroa mites in the Vengerian apiary, the use of organic acids was ineffective; this technique only allowed restraining the growth of the population. Therefore, a preparation based on amitraz is used in the form of strips placed inside the nest after the honey is pumped out in the late summer - early autumn period before the families are placed in the winter house. Over the past five years, the apiary's hatching rate has not exceeded $1.5 \%$. The content of residual amounts of the drug in beekeeping products was not determined.

Scientific publications for the period 1987-2016 regarding modern threats to honeybee populations prove that the predominant negative factors are not diseases and pests, but climate change, landscape change, agricultural intensification and invasive species. Hence, the authors see the need to restore and improve forage resources and shelters for bees through the ecological intensification of diversified farming systems, as well as harmonization of beekeeping with the preservation of wild pollinators [22]. Industrial agriculture, in particular large-scale monoculture, has a negative impact on beekeeping. The negative impact of an increase in soybean cultivation on the production of Argentine honey due to a decrease in yield in the period 1996-2016 was noted. The results indicate that the expansion of soybean acreage since 1996, which included the replacement of natural habitats with extensive agrocenoses, the intensive use of transgenic seeds, agrochemicals and technology, was associated with a $60 \%$ decrease in honey productivity of bee colonies [23]. The ability to avoid such threats is associated with the specifics of the location of beekeeping farms in biocenoses that are not related to agricultural use. On the territory of the West Siberian region of the Russian Federation, such opportunities are realized.

Analysis of various beekeeping practices in Finland has shown that an increase in world food security is real, provided that bee colonies are used for pollination and that, in addition to honey, protein products such as bee pollen and homogenate of drone larvae are obtained. In this case, the impact on climate change, land use and freshwater use (for honey 
production was estimated at $-0,33 \mathrm{~kg} \mathrm{CO}_{2}$-еq $\mathrm{kg}^{-1},-7,89 \mathrm{~m}^{2} \mathrm{~kg}^{-1}$ и $14,01 \mathrm{~kg} \mathrm{~kg}^{-1}$ respectively) was positive [24]. Experience of using protein products of beekeeping, obtained in apiaries in the south of Western Siberia, gives positive results in the food industry and in veterinary medicine $[25,26]$ and this makes it possible to practically implement both the concept of food safety and solve problems of environmental safety.

Recent research from 80 published articles on plant-pollinator interactions provide insight into how Apis mellifera and potential changes in its range and abundance determine the ecology, evolution and conservation of plants, pollinator insects and their interactions in their natural habitat. [27]. The decline in insect pollinators is a problem for humankind, driven by the history of land use, changes in technology and socio-cultural attitudes that are causing this problem. [28]. Analysis of beekeeping technology in Europe in terms of risk assessment and management showed the key role of the beekeeper in the formation of the general condition of bee colonies [29]. The call to "save the bees" should be a call for changes in agriculture towards "greening" it and increasing the share of organic beekeeping. In Russian Federation, programs of additional professional education in the field of ecology have been developed and are being implemented in order to understand and practically solve these problems in beekeeping for beekeepers [30].

The fate of insect pollinators has recently been a source of both public and academic interest and concern. However, according to researchers in Australia, declining pollinators are often misinterpreted as a threat to effective crop pollination, and this could lead to unwarranted efforts to protect introduced and / or widespread pollinator species such as honeybees and others at risk pollinator species are neglected. The authors argue that honeybees outside their range are not suitable as a primary pollinator [31].

As for the territory of Russia, no more effective pollinators of cultivated entomophilous plants than A. mellifera have been found so far. An exception is the pollinator of some clover species, Trifolium sp., of which the bumblebee species, Bombus spp., are the most effective. The widespread practice of organic beekeeping at present in Russia cannot be associated with the use of agrocenoses, since their share, certified as organic, makes up an insignificant part of agricultural lands in Russia. In this regard, the realization of the pollination potential of honey bees in combination with the development of organic beekeeping in the Russian Federation is a matter of an uncertain future. Probably development of two directions in beekeeping: first based on the realization of the potential of agrocenoses due to the pollination of bees and the second - organic beekeeping, realizing the idea of food security, environmental stability and sustainable development.

Organic beekeeping food is a beekeeping product intended for food, produced in an organic way, if the requirements for organic production have been met for at least one year. Some authors associate the difficulty of obtaining a certificate for peasant farm and individual entrepreneurs in beekeeping with the misinterpretation of the rules by experts and the complexity of collecting documentation, it is proposed to finalize the standards in the field of organic production and develop comprehensive instructions and regulations for examination [32]. The transition period to the organic method of farming begins from the moment the application is submitted to the body that carries out the procedure for confirming compliance with GOST 33980-2016. The duration of the transition period, during which the rules of organic beekeeping are applied, is at least one year. Products manufactured during the transition period are prohibited from labeling and marketing as organic. Cost of certification procedures is major constraint on the growth of the organic sector in Russian Federation. 


\section{Conclusions}

1. Quality and safety of organic beekeeping products are regulated by the current standards for traditional beekeeping products. No additional indicators confirming the organic origin of the bee product are provided by law, except for the voluntary certification of production. All of above requirements for organic production are generally met in the overwhelming majority of apiaries in Western Siberia. Obviously, in order to realize the competitive advantages of organic beekeeping, the owners of small beekeeping farms in the south of Western Siberia should unite to undergo voluntary certification procedures.

2. The problems faced by producers of organic beekeeping products are: a) control over the populations of Varroa $s p$; b) in absence of certified organic producers of foundation; c) in difficulties of selling beekeeping products as organic.

3. In Russia, the development of two directions in beekeeping is likely: first is based on realizing the potential of agrocenoses and providing pollination services, and second organic beekeeping, realizing idea of food security, environmental stability and sustainable development.

\section{References}

1. D.G. Galkin, International Journal of Humanities and Natural Sciences, 4-2, 160-164 (2019) DOI: 10.24411/2500-1000-2019-10774. https://docplayer.ru/141691170Razvitie-rossiyskogo-rynka-organicheskogo-prodovolstviya-doi.html

2. E.A. Mitina, A.S. Dubko, Agrarian Bulletin of the Upper Volga Region, 4 (29), 120127 (2019)

3. Y.P. Fomichev, Journal of Agriculture and Environment, 1 (9), 5 (2019)

4. Helga Willer, Jan Trávníček, Claudia Meier and Bernhard Schlatter, The World Organic Agriculture STATISTICS \& EMERGING TRENDS 2021, http://www.organic-world.net/yearbook/yearbook-2021.html

5. Union of Organic Farming, URL: https://soz.bio/wpcontent/uploads/2021/02/metodicheskie-rekomendacii-itogovyy-sbornik-may-2021.pdf

6. G.A. Komlatskiy, V.I. Gaiduk, I.D. Kuzmin, Proceedings of the international scientific and practical online conference Priority directions of scientific and technological development of the agro-industrial complex, 215-218 (Novosibirsk, 2020)

7. V.I. Afanasiev, Economics of agricultural and processing enterprises, 4, 20-23 (2018)

8. Tyler P. Quigley, Gro V. Amdam, Gyan H. Harwood, Current Opinion in Insect Science, 35, 132-137 (2019) ISSN 2214-5745 https://doi.org/10.1016/j .cois.2019.08.012.(https://www.sciencedirect.com/science/article/pii/S2214574519300 082).

9. L.A. Osintseva, Innovations and food security 4 (18), $72-84$ (2017)

10. L.A. Osintseva, K.Ya. Motovilov, V.I. Korkina, Agricultural biology, 45 (2), 88-90 (2010)

11. I.I. Kovalchuk, R.S. Fedoruk, Topical issues of veterinary biology 4 (20), 63-67 (2013)

12. L.M. Kovalskaya, R.S. Fedoruk, I.I. Kovalchuk, L.I. Romaniv, Animal biology, 18 (1) 40-45 (2016)

13. L.A. Osintseva, V.I. Korkina, Fundamental research, 7-S, 17-18 (2009)

14. Bilal Ahamad Paray, Indu Kumari, Younis Ahmad Hajam, Bharti Sharma, Rajesh Kumar, Mohammed Fahad Albeshr, Mohammad Abul Farah, Javed Masood Khan, Saudi Journal of Biological Sciences, 28 (1), 1167-1176 (2021) ISSN 1319-562X, 
https://doi.org/10.1016/j.sjbs.2020.11.053, https://www.sciencedirect.com/science/artic le/pii/S1319562X20306185)

15. Rachele S. Wilson, Alexander Keller, Alison Shapcott, Sara D. Leonhardt, Wiebke Sickel, Jane L. Hardwick, Tim A. Heard, Benjamin F. Kaluza, Helen M. Wallace, Agriculture, Ecosystems \& Environment, 310 (2021) ISSN 0167-8809, https://doi.org/10.1016/j.agee.2020.107296 (https://www.sciencedirect.com/science/art icle/pii/S0167880920304825)

16. L.A. Osintseva, Beekeeping 5, 12 (2005)

17. T.S. Bespalova, Beekeeping 3, 25-26 (2014)

18. V.A. Chuchunov, E.B. Radzievsky, V.A. Zlepkin, T.V. Konobley, Yu.V. Radzievskaya, Bulletin of the Nizhnevolzhsky agro-university complex: Science and higher professional education 1 (61), 278-287 (2021)

19. V.A. Chuchunov, E.B. Radzievsky, T.V. Konobley, Beekeeping 4, 26-28 (2021)

20. Angela Fanelli, Paolo Tizzani, Research in Veterinary Science 131, 215-221 (2020) ISSN 0034-5288, https://doi.org/10.1016/j.rvsc.2020.04.017. (https://www.scienced irect.com/science/article/pii/S0034528820301193)

21. Maja Lazarus, Blanka Tariba Lovaković, Tatjana Orct, Ankica Sekovanić, Nina Bilandžić, Maja Đokić, Božica Solomun Kolanović, Ivana Varenina, Andreja Jurič, Marija Denžić Lugomer, Dragan Bubalo, Chemosphere, 266 (2021) ISSN 0045-6535. https://doi.org/10.1016/j.chemosphere.2020.128954.(https://www.sciencedirect.com/sc ience/article/pii/S0045653520331519)

22. A. Decourtye, C. Alaux, Y. Le Conte, M. Henry, Current Opinion in Insect Science 35, 123-131 (2019)

23. G.S. Groot, Agriculture, Ecosystems \& Environment, 306 (2021) ISSN 0167-8809. https://doi.org/10.1016/j.agee.2020.107203. (https://www.sciencedirect.com/science /article/pii/S0167880920303893)

24. Jani Sillman, Ville Uusitalo, Tuire Tapanen, Anneli Salonen, Risto Soukka, Helena Kahiluoto, Science of The Total Environment, 756 (2021) ISSN 0048-9697, https://doi.org/10.1016/j.scitotenv.2020.143880. (https://www.sciencedirect.com/scie nce/article/pii/S0048969720374118)

25. L.A. Osintseva, N.V. Efanova, V.V. Kabysheva, Beekeeping 10, 50-51 (2009)

26. L.A. Osintseva, O. V. Lisichenok, K.A. Pokazanova, Beekeeping, 9, 50-53 (2019)

27. K.L.J. Hung, (Hung, Keng-Lou James), J.M. Kingston, (Kingston, Jennifer M.), M. Albrecht, (Albrecht, Matthias), D.A. Holway, (Holway, David A.), J.R. Kohn, (Kohn, Joshua R.), Proceedings of the Royal society B-biological sciences, 285 (1870), 2017 2140 (2018) DOI: 10.1098/rspb.2017.2140

28. Damon M. Hall, Dino J. Martins, Current Opinion in Insect Science, 38, 107-114 (2020) ISSN 2214-5745

29. Giorgio Sperandio, Anna Simonetto, Edoardo Carnesecchi, Cecilia Costa, Fani Hatjina, Simone Tosi, Gianni Gilioli, Science of The Total Environment, 696 (2019) ISSN 0048-9697, https://doi.org/10.1016/j.scitotenv.2019.133795.https://www.sciencedirect .com/science/article/pii/S0048969719337362)

30. E.A. Shashurina, S.A. Nefedova, L.A. Redkova, Collection of articles of the III International scientific-practical conference "Russia and the world community: problems of demography, ecology and public health", 84-90 (Penza, 2020) 
31. Jay M Iwasaki, Katja Hogendoorn, Current Opinion in Insect Science, 46, 112-118 (2021) ISSN 2214-5745. https://doi.org/10.1016/j.cois.2021.05.005 (https://www.sciencedirect.com/science/article/pii/S2214574521000584)

32. I.N. Mishin, Problems of Application of Requirements for Assessment of the Conditions for the Production of Organic Beekeeping Products, In the collection: Collection of materials of the international scientific and practical conference Topical issues of the development of organic agriculture, 273-281 (Smolensk, Publisher: Smolensk State Agricultural Academy, 2018) 